\title{
Disasters And Political Ecology: The Case Of Flood In Tahura Bukit Barisan Zone
}

\author{
Fernanda Putra Adela1, Adil Arifin², Salwendri ${ }^{3}$
}

\author{
Faculty Social And Politic \\ University Of North Sumatera \\ fpadela@usu.ac.id
}

\begin{abstract}
This research, describes and analyzes the Disasters and Political Ecology; Case of Floods in Tahura Bukit Barisan Region. The point of the problem is the destruction of forests in the area of Forest Park (Tahura) Bukit Barisan which cause damage to the Watershed (DAS). As a result of the flood damage occurred in the last week of May 15, 2016. 76 victims of tourists visiting 21 of them died and some were injured. The question in this study is what the right model in the management of Forest Park (Tahura) Bukit Barisan Ecotourism Region Waterfall Two Colors in the Perspective of Political Ecology. The theoretical framework of this research using ecological political theory and the theory of public policy. The researchers then mapped the role of different stakeholders such as central government, local governments, businesses, NGOs and communities. This study is a qualitative research with a critical paradigm to explain phenomena by placing an interview as the primary data and books and international journals and national journals as secondary data. Results from this study showed that the importance of strengthening the role of the stakeholders (stakeholders) in forest management, Evaluation of Forest Management, Preventive Actions Actors Illegal logging. Furthermore, researchers also explained about the possible establishment of regional Waterfall Two Colors as a new tourist area in North Sumatra.
\end{abstract}

Keywords: Disaster, Ecotourism, Political Ecology

\section{INTRODUCTION}

most worrying problem in the 21st century, in addition to the economic crisis, the crisis of racial and corruption is the environmental crisis is the cause of the disaster. A disaster is a serious disruption of the functioning of a society, causing widespread loss of human life in material terms, the economy or the environment and that goes beyond the ability of the community concerned to cope using

their own resources. Environmental catastrophe currently occurring in many countries resulting in misery, disease and death. Causes include; floods, landslides, forest fires, heat waves, until the smoke haze caused by environmental damage.

This condition is experienced by North Sumatra Forest today that the longer-increasingly damaged the environment, especially in forest management. Where from year to year in North Sumatra deforestation rates higher. According to data from the Forestry Ministerial Decree No. 44 of 2005, the forest area in North Sumatra is 3.74212 million hectares. However, the longer this figure has decreased significantly because it was a lot of damage to forests caused by deforestation. In the period of last 10 years (2005-2015) there are over 206,000 hectares of forest in North Sumatra has suffered damage due to illegal logging, encroachment and illegal logging are sporadic and massive.

On May 15, 2016 that the flood occurred in the District of Sibolangit, Deli Serdang regency, North Sumatra. The floods caused by the overflow Watershed (DAS) upstream of the tourist area Waterfall Two Colors Sibolangit to cause a flood. The flood water then irrigates the 
river which was a watershed downstream Sinembah Waterfall Two Colors. According to data released by BPBDs Deli Serdang district there are 76 tourists who visit the ecotourism area Waterfall Two Colors Sibolangit at that time, 21 of them died.

Waterfall Two Colors are beautiful Niagara Region Ecotourism which has a color gradation two different water located in the district of Sibolangit that its watershed is located in the Forest Park neighborhood (Tahura) Bukit Barisan. Where Tahura Bukit Barisan's a management unit that core area of protected forests and conservation areas covering Forest Preserve Sibayak I and Simancik I, II and Protected Forest Simancik II Sibayak and Sinabung Protected Forest covering an area of approximately 51,600 hectares. Named Waterfall Two Colors for structurally, water being stored from the waterfall shower canescent while waterfall located on the edge of the Regional waterfall spills from the top of a light blue.In the last few years. Waterfall Two Colors became a destination very much in demand and is visited by tourists, especially students in North Sumatra. Exotic nature Waterfall Two Colors become extraordinary appeal for visitors who want to enjoy the beautiful nature.

Current condition of the Bukit BarisanTahura more alarming, of which about 600 hectares of forest in the last 10 years was severely damaged due to illegal logging and land conversion. Destruction of forests will automatically lead to the destruction of the watershed in the area of Forest Park Bukit Barisan will automatically lead to landslides because of inability to resist soil erosion. This then results in the formation of scrap wood pile in the upper watersheds Waterfall Two Colors. Pieces of the wood pile to form a dam that holds water that at times can come loose and causing widespread flooding.
During this time the management of ecotourism Waterfall Two Colors is managed by the Center for the conservation of Forest Park (Tahura) II under the coordination of the Forestry Service of North Sumatra Province. That is, management, revenue (PAD), conservation and rehabilitation did not involve local government Area near Waterfall Two Colors are. As; Deli Serdang District Government and the Government of Karo.

This is certainly different from the model of forest management being undertaken by many countries including Japan, Brazil and South Korea. Where the forest management involving all stakeholders (stakeholders) such as; The central government, local governments, businesses, NGOs and local communities. Of stakeholders those have different interests in terms of forest management. Good forest management is certainly minimize the chances of a disaster. According to Bryan (1998) Yardstick of success an area managed to overcome the problems in dealing with disasters such success is never separated by the patterns of cooperation that do different stakeholders involved. Moreover, the disaster has routinely occur from time to time.

Various policies in tackling the disaster has been done by the government through legislation. In particular legislation concerning the conservation Forest Park Raya example, Law No. 5 of 1990 about the conservation of the Natural Resources and Ecosystem, Perda North Sumatra Province No. 8 of 2013 on Disaster Management, Law No. 24 of 2007 on Disaster Management, Law oF Number 26 of 2007 on Spatial Planning Disaster and Government Regulation of 2008 on the Disaster Management. However, it is not enough to prevent a catastrophe in North Sumatra, particularly the Deli Serdang.

Realizing there are many forests management Raya Taman Bukit Barisan 
Ecotourism Region Two Colors not optimal in preventing and reducing the risk of disaster. Attracting the author to conduct research with the object of finding Model Forest Park Management (Tahura) Bukit Barisan Ecotourism Region Waterfall Two Colors In Perspective of Political Ecology.

\section{METHODS}

This study used qualitative methods. Where researchers collected data by in-deep interviews (depth interview) with the various speakers who have the capacity and capabilityrelated disasters, environmental politics, government, NGOs and communities. In determining interviewees researchers using purposive sampling technique in which researchers directly determine the resource in accordance with the capacity and competence related to this research. Researchers interviewed the Head of the Protection Unit business Tahura Bukit Barisan Dandy Simbolon, Executive Director of Forum for Environment (WALHI) North Sumatra Dana Tarin, Professor of Social USU (Expert Anthropology Environment), the Forest Service Karo / Deli Serdang, Regional Disaster Management Agency of North Sumatra Tri Barus and Society. Researchers also collected a variety of other forms of qualitative data such as documents that are useful for the development of a deeper understanding of this research.

\section{RESULTSAND DISCUSSION}

\subsection{Strengthening the Role of Stakeholders}

Political Ecology by Raymond L. Bryant (1982) is a study of political dynamics surrounding material continuous struggle whose primary focus in the third world environment. As the most important theme is the role of unequal power relations in the constitution of the environment increase political awareness. Political ecology focuses on the community level relating to the environment, which in turn gave birth to a social change and conflict. The main assumption of political ecology related to "environmental change and ecological conditions are (to some extent) the product of political processes". If the state of the environment is the product of a processa-political process, it is not apart in this case is the involvement of the process-a dialectical process in politics and economics.

The state's role as a facilitator of the capitalist system dealing with the environmental problems presented by the system. Should the state as an actor who maintain environmental sustainability. However, because the entangled system of capitalism, the state is more likely to give priority to the interests of capitalism. Growing industrialization has two implications. First, the state-sponsored search associated with efforts to maximize the extraction of natural resources such as third world countries do the extraction for export. This process of economic and political marginalization accelerategrassroots actor stend to be weak. Second, the state-sponsored industrial development related to air pollution, soil and water rising from the manufacturers do. Third world countries attract transnational companies and establish local industries.

Natural resource management in third world countries are conceptual related to regional autonomy. Where aspects of regional autonomy with regard to the political demokratization of the national and regional levels. This includes the following two aspects. First, democratization associated with the realization of checks and balances among the branches of power are important in the area. Second, democratization is associated with an increase in the various elements of the local community in controlling the local government clean 
and democratic for the realization of civil society.

Since the new order, the Indonesian Forest is positioned as a renewable resources (natural resources that can be renewed). That policy led to the exploitation of timber production for gaining foreign exchange for the state revenue through licensing policy Forest Tenure (HPH) to build the forestry industry, such plywood as(plywood), sawmill, pen and paper. That policy should be recognized that the Indonesian economy is increasing significantly, seen from the magnitude contribution forestry sector gross domestic product (GDP) of Indonesia in 1980-1990.

Massive exploitation of forests has resulted in huge foreign exchange. Through an increase in GDP, the position of Indonesia was lifted from the group of poor countries into groups of intermediate state. However, unfortunate management of forest resources that are not based on continuous and occur relatively uncontrolled logging is not due to lack of enforcement of forest spoiler. Though implemented method of logging timber barons are sustainable, thus requiring a super tight control to prevent overexploitation (over exploitation), which resulted in severe damages semain environment. The reality is that forest exploitation impact on the development This was confirmed by Mr. Koesnadi who said:

"The central government should learn from the mistakes of the new order. New Order era centralized central government has full authority over the forest. Strengthening the central government would do not have to like the new order but developed only law

Means that the government has authority to strengthen his position with the aim of a more balanced management. The central government were to give room for the stakeholders to walk on their own with overlapping policies. of corruption, collusion and nepotism $(\mathrm{KKN})$.

Policies on forest management is not enough with laws and legislation that are centralized and top-down. Such policies resulted in forest management relying solely on law enforcement alone and just give a little space on the local community to participate.

In the case of the management of the management of Forest Park (Tahura) Bukit Barisan far only rely on regulatory law No. 5/1990 on Conservation of Biological Resources in the hands of the provincial government in which his memory is managed by the Forest Service of North Sumatra in cooperation with the Park Forest (Tahura) Bukit Barisan. Perception central government on Forest Parks maintained and preserved, to function as one of the last strongholds in an effort to preserve the forest.

The concept of management of Forest Park (Tahura) who developed the models to make the Hall of Forest Park (Tahura). This model is based on the criteria of breadth Tahura, conservation value and the condition has been recognized both nationally and regionally. Where to Tahura Bukit Barisan located in 4 counties; Simalungun, Langkat, Karo and Deli Serdang regency.

enforcement system of the roof assigning supervisors investigators and prosecutors specialized in the coordination of direct central government to the relevant parties in Forest Park (Tahura) Bukit Barisan "It

Opinion of MrKoesnadi (Chairman WALHI North Sumatra) are corroborated by Prof HamdaniHarahap said: 
"Permit the enterprise Forest Industrial Park in the central government. Although the regulation could embodied Provincial Office. If there is any company that violates the

While the local government in relation to the need for preservation of Forest Park (Tahura) by various stahkeholdersincluding local governments.Then the conflict of interest to manage Forest Park (Tahura) either under decentralization between the central government (Ministry of Forestry) and regional (provincial and "As long as there is no upper PAD Tahura management related natural resources at disposal. Both, Sibayak or Mount Sinabung, located in Karo district there is no regulation

According to Tarin Fund who explained;

"Community Social Institution or often referred to as Non GovernmentOrganitation (NGO) is slaah an important actor in the preservation of forests including Forest Park. Non"Governmental Organization (NGO) emerged as a form partisisipation in a changing environment. Governmental Organization (NGO) not only moves in the realm of the implicate damage to the environment, but also on the influence of environmental damage in humans

Then the role of businessmen in Bukit BarisanTahura not be separated from economic interests. Economic interests with regard to employers as the main actors. Substantially natural resources was utilized to improve the welfare of a sustainable society, only in its management, the conditions are such that can not be understood by the people

"Actually in the Waterfall Two Colors no entrepreneur because it is not a tourist area. But the perspective we have only looked at what is beautiful as a tourist. Though not all beautiful it can be used as tourist attractions. There are values that are more just that. Entrepreneurs and even then there ya food entrepreneurs of small traders

"Employersas one of the stakeholders in the management of Taman Hutan Raya should also pay attention to values of ecological. Employers should view the forest as an asset for a period of view of life has far government has full authority to pull it out For example the company at odds with environmental sustainability. It should be strengthened central government ".

district) are eligible to be reviewed. Perception of local government such as existence and preservation of Forest Park Botanical (Tahura) is very important for the conservation of the environment and can be enjoyed by stakeholders theinregion.This is confirmed by Martin Sitepu saying;

that says it is a tourist location. Everything was illegal

governmental often defined as a non-profit, community groups volunteered both held at the local, national or international levels

who live in the area of Forest Park (Tahura) Bukit Barisan.

On the other hand employers have only to see the forest merely were selling timber high, so if it will be able to finance the ongoing development. That is why due to the abundance of economic resources, the effort or the desire to exploit region with local government efforts to improve the original income (PAD), either through a levy collected from the owners of capital.

According to information from Dandy Simbolon said:

"This was confirmed by Dana Tarigan

our understanding about just look at the profit side. I categorize that the act of illegal logging in the watershed Two Tahura regardless of color or not is the act of lumbermen

more benefit than the value of timber alone only.In the meantime communities have a central role as one of the stakeholders in sustainability in the Forest Park neighborhood Raya Bukit Barisan .. 
According to DediSinuhaji who said:

"The public is the victim, the community could also actors, government officials before so is society. Society must be strengthened in the management of forest improvement in highway SibolangitForest

"Society is detached from policy makers for policy in local government or central government. However, the public also has a role as one of the stakeholders because oversee seriously is a vital part for the community

\subsection{Evaluation of Forest Management}

Indonesia has a total forest area of approximately 109549 million ha (FAO 1993). Consist of a limited production of 31 million ha, permanent production forest area of 34 million ha. Conservation forest (can be transformed to enable) for other purposes an area of 30 million ha of forest konservation for the allocation of the National Park covering an area of 18 million ha, and the protected forest area of 30 million ha. The role of forest conservation is very significant to analyze its contribution to regional autonomy. As is known, one tree with a diameter of $30 \mathrm{~cm}$ can absorb gas emissions $\left(\mathrm{CO}_{2}\right) 2.6$ tons / per year. Indonesia forest where categorized into National Parks, Nature Reserves and Forest Park

This is a form of policy overlap. Where as a result of the regulation encroachment and land use so as justification for the destruction of forests.

\subsection{Preventive action Actors Illegal logging}

Monitoring of the Forest Park There are still not maximized, especially in

"In Tahura there are four districts that are supervised covering Karo district, Deli Serdang, Simalungun and Langkat. However,

"Means that preventive action is done by the rule changes are more in line with adding personnel in the field. In order for what the objectives of the supervision of the forest may soon.damage prevention
Park. Therefore, if a disaster happens then not look at society in which all taxable event of a flood. At the time of the flood in Tahura yesterday, I took into the forest and waterfalls that

Forest Park Kingdom which covers 51,600 hectares is an area that is managed by the North Sumatra governor as an area of nature protection or better known as a conservation area. According to the laws in force, this region can not be managed and used for a particular purpose.

The concept of management of the partnership or collaborative management of multi stakeholders inviting highly popular articles used in this reformation regime. However, the actual end of the new order of government in the 1990s, the concept of management of this partnership has been widely implemented in the field in the management of the forestry sector, in particular the cooperation of the National park office and other stakeholders. Or in other words, used to be when the New Order, the management of the centralized nature known as government-based management (statebase management).

terms of the behavior of the crackdown on illegal logging, land conversion and forest encroachment. Where weak oversight for personnel authorities only limited coordination alone.

This was confirmed by Dandy Simbolon said;

the number of personnel who watch only 8 people. It makes our sometimes overwhelmed in overseeing the vast Tahura reach 51,600 ha forest in Forest Park during the highway is already done optimally with the supervision of the Forest Police, Arrest in place until a legally cracking down the illegal logging my head. However, it has 
not been able to drastically reduce the perpetrators of illegal logging because of limited personnel and forest area supervisor Tahura reached 51,600 ha. Where in overseeing forest research recommendation is to use drones.

Drone or more would be known as unmanned aircraft generally regarded as military weapons or means of surveillance. Often referred to as unmanned aerial vehicles (Commonly Referred to as an unmanned aerial vehicle) systems,unmanned air (Unmanned Aerial System) or remotely piloted aircraft (Remotely piloted Aircraft),Unmanned aircraft can also provide low-cost solutions and lowimpact for environmental surveillance in maintaining the ecosystem. Drone used for conservation purposes such as "ecodrones. This is due to the use of drones has the agility and excellent imaging quality and the ability to map the environmental monitoring.Besides the drones can function as monitoring mechanism real-time in case of disaster or illegal logging occurs then distribute the latest message and send what happens next. On the other hand drone capable of flying at a distance can be adjusted by a computer system.

"Ifhe government wants, the government could use drones to monitor forest. To overcome forest destruction Forest Park Kingdom. The problem is the government does not want to solve this Indonesia is a country that has the best tropical forest in the world after Brazil. If seen from the costs incurred by the Brazilian who is only 10 million dollars, equivalent to $130-140$ billion rupiah very little compared to a loss of State Indonesia due illegal logging. According to data from Study of Indonesia Corruption Watch (ICW) during the period 2004-2010, state losses due to illegal logging in Indonesia reached $\mathrm{Rp} 169.7$ trillion.

\subsection{Implentation on Ecotourism Policy}

Developed countries like the United States, Russia and Canada have long been using drones to monitor the situation of their forest-related illegal logging. Not only that even in March 2015 that the Brazilian government has launched an anti-illegal logging unit or new security forces in a bid to tackle illegal activities, encroachment and illegal forest conversion. Brazil uses 200 units of drones to monitor the smuggling of illegal timber in the Amazon rainforest.

This is done to monitor and illegal logging activities control rife in Brazil. The Brazilian government has invest 10 million dollars to buy the drones and it has halted the illegal logging in Brazil up to $80 \%$ loss of their country. Gains derived by the use of drones is lightweight and easy to transport, high-resolution, low cost operations, can fly at different heights depending on the data, can map areas are inaccessible by car ship data video recording capabilities and the availability of rapidly processing the raw data.

According Kusnadi who said:

problem because the local government in Langkat and businessmen were the same, and the same person. Drone was very effective while costs more than what would have been prevented "

Understanding stakeholder or actor discourse stakeholders on the existence and the national park. The actors stakeholders have a central role in implementing co-management. For example the role of the central government, provincial government, local government funding for the development of the World Bank and the Foundation, whether international or domestic NGOs and the public has not become a policy issue local governments (LGs). In fact, there are some half a district government even more allocation 
of land used for national land conservation. For example Bukit Barisan Forest Park.

In a period of some time. Niagara Region Two Color is not used for ecotourism, but the fact the field that the area is used for tourism secretly (illegal). This condition is very alarming because if a disaster occurs there is no government responsibility in this regard.

Ecotourism also means involving local communities in the process so that

Management of Niagara Region Two current colors in substance does not officially opened. However, the opening Waterfall Two Colors as ecotourism can be used for a "However,as the establishment of ecotourism Waterfall Two Colors should along with regulations that do not overlap. This means that all stakeholders should work together for the establishment of Tahura as ecotourism.

\section{CONCLUSIONS}

point problems facing Indonesia in the last decade is a disaster caused by environmental damage. Flash floods, erosion and drought almost every year up to the people of North Sumatra. Flood that occurred in the week of May 15, 2016 in ecotourism Waterfall Two colors are located in the District of Sibolangit, Deli Serdang regency, North Sumatra is among the disaster. Of the 76 tourists who visit Niagara two colors at the time, 21 people died and some were injured. In addressing the problem, collaborative forest management among stakeholders (stakeholders). Like the central government, local governments, employers, Social Institution (NGOs) and communities together is the best option. On the other hand the determination of the region Waterfall Two Colors Hill Forest Park ranks as an ecotourism area they can obtain social-economic benefits. Definition of ecotourism has developed over time. But in fact, the definition of ecotourism is a form of travel that is responsible for the preservation of pristine areas, receive economic benefits and maintain the integrity of culture Karo and Deli Serdang.

According to Tri Barus who said:

responsibility and repairs as well as supervision. It even led to the occurrence disaster

in collaborative governance is the best choice. Of course, with the close supervision of government supported by legislation.

\section{ADVICE}

Suggestion of this research is a scheme of a new model developed by researchers. Recommendation Scheme Management Model Forest Park (Tahura) Bukit BarisanEkowista Niagara Region Two Color Schemes in the Perspective of Political Ecology Political Ecology in the book Sinead Bailey and Raymond Bryant called Third World Political Ecology approach that emphasizes the actor. Where mapping in the mapping of these actors with regard to stakeholders (stakeholders)in Forest Park (Tahura) Bukit Barisan. Namely the Central Government, Local Government, Employers, Social Institutions (NGOs) and Community.Where the recommendation to this model is the one-stop management (partnership) between stakeholders with clear regulations under the auspices of the central government. 
Scheme Management Model Forest park (Tahura) mountain chain Region Ekowista Waterfall Two Colors In Perspective Of Ecological Politics

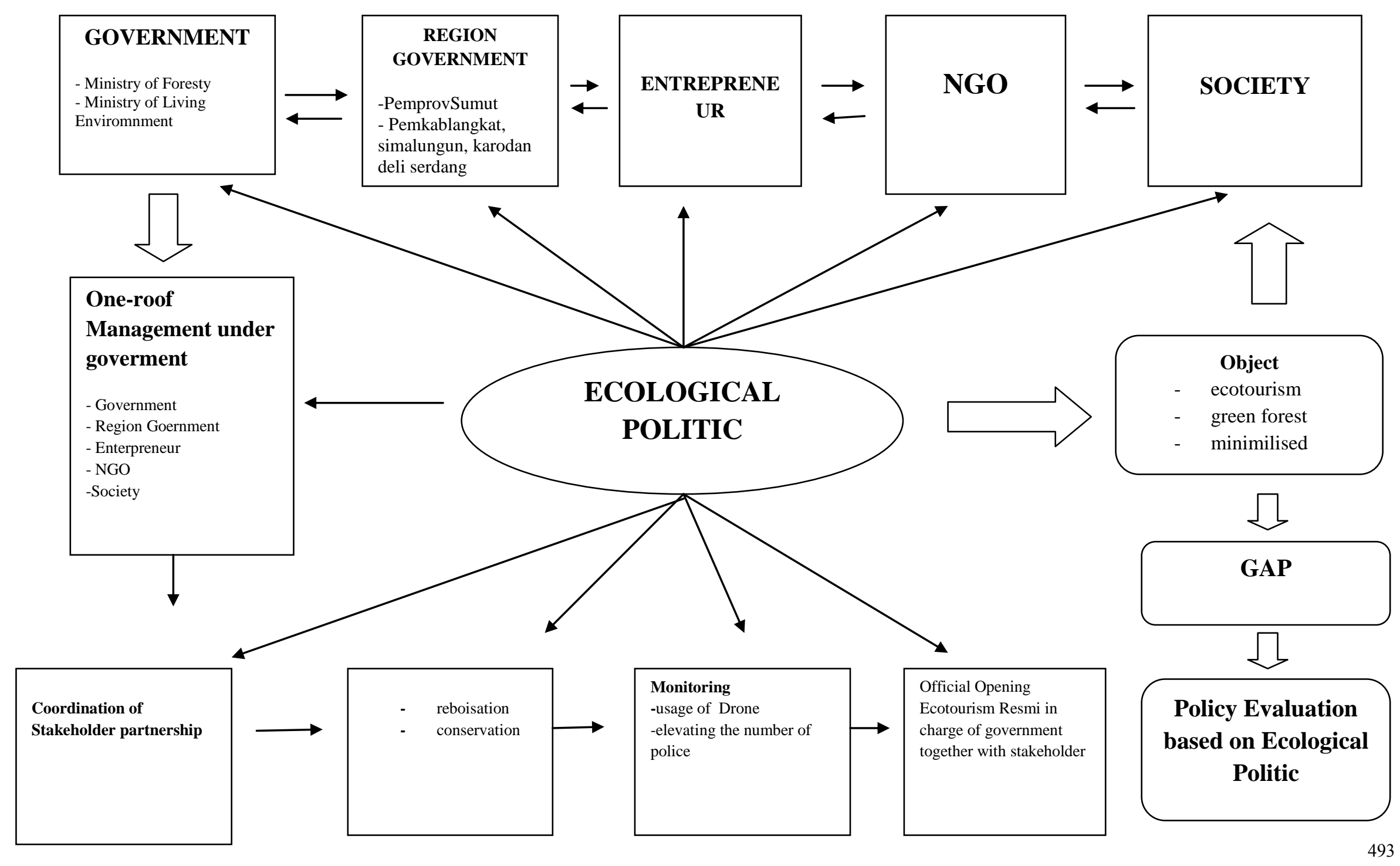




\section{REFERENCES}

Akib,

Muhammad,

2012

PolitikHukumLingkungan

(DinamikadanRefleksinyadalamProdu

kHukumOtonomi Daerah), Jakarta :Rajawali Pers.

Bryant, RaymodL, 1998, Power, Konowlegge and Political ecology in third world : a review London : Departemen Of Geography.

Hidayat, Herman,2015, PengelolaanHutan Lestari : Partisipasi, KolaborasidanKonflik, Jakarta : YayasanPustakaObor Indonesia.

Ramli, Soehatman, 2011, PedomanPraktisManajemenRisikodal amPerspektif K3 OHS Risk,Jakarta : KPG.

Johnson, Julia, "Turning the tide in Flood Control (With support and guidance from FEMA, local governments are establishing partnership for floodplain management and mitigation", 211, Washington DC : Jurnal American City and County. Hal.120-137.

Jabradshaw , Corey, NavjotsSodhiw, Kelvins Pehwzdan Barry Brook "Global evidence that deforestation amplifies flood risk and severity in the developing

world"dalamJurnalInternasional

Global Change Biology yang di publikasipadatanggal 1 Juni $2007 \mathrm{di}$ Australia. Hal 2379-2395.

Koh, L.P. and Wich, S.A., 2012.Dawn of drone ecology: low-cost autonomous aerialvehicles

for conservation.Tropical Conservation Science. 5(2), 121-132. Available online:

www.tropicalconservationscience.or

Someshwar,Shiv Rizaldi Boer dan Esther Conrad, Managing Peatland Fire Risk in Central Kalimantan, Indonesia World Resources Report Case Study, JurnalWorld Resources Report. Hal.120.
Saragih, Anwar, 2016, Model PenanggulanganBencana di Kawasan Taman NasionalLeuser, 2016, Semarang: JurnalPolitika No.7, tanggal 1 April 2016.

Fransiska, EmmiManurung, Penegakanhukumlingkunganterhadap ilegalLogingdalamupayaperlindungan hutan di KabupatenBungo Jambi, Magister HukumEkonomi, Universitas Indonesia : Depok 2007

Harian Tribun: Pencarian Korban Banjir Bandang Dua Warna Resmi Dihentikan http://medan.tribunnews.com/2016 /05/28/pencarian-korban-banjirbandang-dua-warna-resmidihentikandownloaded on $4^{\text {th }}$ June 2016 , at 13.34 wib.

Mangobay

:RatusanHektarHutanLindungTahura SibolangitTerbabat http://www.mongabay.co.id/tag/ker usakan-hutan-sumatera/ downloaded on 4thjune 2016, at 18.00 